\title{
Identification of rye- and wheat-types of Pseudocercosporella herpotrichoides with DNA probes
}

\author{
Didier Thomas, ${ }^{1,2}$ Henri Maraite ${ }^{2}$ and Marc Boutry ${ }^{1 *}$ \\ ${ }^{1}$ Unité de Biochimie Physiologique and ${ }^{2}$ Unité de Phytopathologie, Université Catholique de Louvain, Place Croix du Sud, \\ 2-10, B-1348, Louvain-la-Neuve, Belgium
}

(Received 10 April 1992; revised 18 June 1992; accepted 27 July 1992)

\begin{abstract}
A partial genomic library of the plant-pathogenic fungus Pseudocercosporella herpotrichoides was prepared in a bacterial plasmid vector. Plasmids from 20 random recombinant clones were radioactively labelled and used as probes in Southern blot experiments with genomic DNA isolated from seven isolates belonging to the rye-type and four isolates of the wheat-type of $P$. herpotrichoides. Most of the probes tested revealed polymorphisms between the two types. In addition, some of them distinguished different isolates within each type. One probe that gave strong hybridization signals may correspond with repetitive DNA sequences. It was shown by dot-blot hybridization to be specific to all the wheat-type isolates tested.
\end{abstract}

\section{Introduction}

Pseudocercosporella herpotrichoides (Fron) Deighton causes eyespot, a widespread disease of wheat, barley and rye in temperate areas (reviewed by Fitt et al., 1988). It is an important component of the parasitic complex of cereal stem-base rot in association with Rhizoctonia spp. and Fusarium spp. (Goulds \& Polley, 1990). After germination, the mycelia spreads through successive leaf sheets to reach the inside of the stem. Economic damage does not occur until the fungus penetrates the stem and interferes with sap circulation. Yield losses in untreated fields can reach $4-30 \%$ of total production and vary greatly according to field location and season (Lagneau $e t$ al., 1986).

Pathogenicity, growth and morphological variations within the species have given rise to several attempts at subspecific classification (Lange-De La Camp, 1966; Scott et al., 1975). Possibly the most accepted system divides the species into wheat type (W-type) and rye type (R-type). The W-type is more pathogenic to wheat and barley than to rye seedlings and produces green-togrey colonies with smooth margins and a high growth rate when grown on agar media. The R-type is equally pathogenic to wheat as to rye seedlings, its colonies are beige-to-brown with feathery margins, and it grows on agar media at approximately half the rate of W-type

\footnotetext{
* Author for correspondence. Tel. 10473621 ; fax 10473872 .
}

Abbreviation: RFLP, restriction fragment length polymorphism. isolates. Nirenberg (1981) distinguished two varieties based on spore size and morphology: $P$. herpotrichoides var. herpotrichoides, characterized by small and generally incurved conidia, and $P$. herpotrichoides var. acuformis, characterized by larger, straight conidia. Leroux \& Gredt (1988) proposed an identification of isolates according to their resistance to fungicides and their growth rate. King \& Griffin (1985) and Sanders et al. (1986) considered that slow-growing colonies could be classified as R-type or $\boldsymbol{P}$. herpotrichoides var. acuformis, and fast-growing colonies as W-type or $P$. herpotrichoides var. herpotrichoides, but this was invalidated by Mauler \& Fehrmann (1987) as the growth-rate ranges of the two types appear to overlap.

Typing of $P$. herpotrichoides strains occurring in the field is important for decision-making in eyespot control. The sensitivity of R-type strains to triazole fungicides is low (Leroux \& Gredt, 1988). Resistance to benzimidazole fungicides is generally more frequent among R-type than W-type strains (King \& Griffin, 1985; Maraite et al., 1985; Fitt et al., 1988). This can, to some extent, explain the population shift towards the R-type observed since the early eighties (Hollins \& Scott, 1987).

Better understanding of variations in field populations and fungicide resistance requires identification of a large number of isolates. However, pathogenicity tests are time-consuming and the results tend to vary with experimental conditions (Fitt et al., 1988; Creighton, 1989 ; Creighton \& Bateman, 1991); in addition, morphological criteria vary widely within subspecific taxa of 
P. herpotrichoides (Maraite et al., 1985; Hollins et al., 1985; Creighton, 1989; Creighton \& Bateman, 1991). New and reliable identification methods are thus required. Electrophoresis of total proteins has been used, but the resulting band patterns are complex, and only a few bands are truly characteristic of each type of $P$. herpotrichoides. So far, isoenzyme patterns have given variable results according to the enzymes analysed (Wegge et al., 1991). Serological identification methods have been studied (Lind, 1990), but their discriminatory power at the subspecific level is low. For these reasons, a molecular approach to the problem was adopted, to seek varietal differences at the genomic level.

This paper describes the preliminary results of a molecular approach which allows the varietal differentiation of $P$. herpotrichoides by restriction fragment length polymorphism (RFLP) and dot-blot hybridization, avoiding misidentification with fungi such as Microdochium nivale and Rhizoctonia cerealis which cause similar symptoms on the cereal foot (Goulds \& Polley, 1990).

\section{Methods}

Fungal strains. Eleven isolates of Pseudocercosporella herpotrichoides were chosen from our collection according to their morphology, growth rate and fungicide sensitivity. One strain each of Rhizoctonia cerealis and Microdochium nivale were also included (Table 1). Cultures were stored at room temperature on $3.9 \%$ (w/v) potato dextrose agar (Difco) and covered with sterile water and paraffin oil. After regeneration of the mycelia on potato dextrose agar, sporulation was obtained on a poor medium [Sach's nutrient agar: $0.1 \% \mathrm{KH}_{2} \mathrm{PO}_{4}, 0.1 \% \mathrm{KNO}_{3}, 0.05 \%$ $\mathrm{MgSO}_{4} .7 \mathrm{H}_{2} \mathrm{O}, 0.05 \% \mathrm{KCl}, 0.02 \%$ glucose, $0.02 \%$ saccharose, $1.7 \%$, $\mathrm{w} / \mathrm{v}$, agar (Oxoid)], after incubation for 3 weeks at $8{ }^{\circ} \mathrm{C}$ by exposure to near-ultraviolet radiation. Spore suspensions were used to inoculate $100 \mathrm{ml}$ of $\mathrm{MM}$ medium $(2 \%$, w/v, glucose, $0.15 \%$ asparagine, $0.1 \%$ $\mathrm{KH}_{2} \mathrm{PO}_{4}, 0.05 \% \mathrm{MgSO}_{4} .7 \mathrm{H}_{2} \mathrm{O}, 0.001 \% \mathrm{FeCl}_{3}, 0.1 \%$ yeast extract). After culture in the dark for $17 \mathrm{~d}$ at $16{ }^{\circ} \mathrm{C}$, mycelium was harvested by filtering through Whatman paper no. 4 , rinsed with sterile distilled water, frozen in liquid nitrogen, and stored at $-70^{\circ} \mathrm{C}$.

Preparation of DNA. DNA extraction from $P$. herpotrichoides and a Penicillium sp. was carried out according to the procedures of Rogers \& Bendich (1988), modified as follows. Frozen mycelium $(10 \mathrm{~g})$ was ground in a mortar and pestle with $2.5 \mathrm{~g} \mathrm{Al}_{2} \mathrm{O}_{3}$ in the presence of liquid nitrogen and mixed with $18 \mathrm{ml}$ of $2 \times$ CTAB solution $[2 \%, w / v$, cetyltrimethylammonium bromide (CTAB), $100 \mathrm{mM}$-Tris/ $\mathrm{HCl}, \mathrm{I} \cdot 4 \mathrm{M}-$ $\mathrm{NaCl}, 20 \mathrm{~mm}$-EDTA, 1\%, w/v, polyvinylpyrrolidone (PVP), pH 8.0] prewarmed to $65^{\circ} \mathrm{C}$. After incubation for $5 \mathrm{~min}$ at $65^{\circ} \mathrm{C}$, the suspension was divided and placed into two glass tubes. The aqueous phase was extracted with an equal volume of chloroform/isoamyl alcohol $(24: 1, \mathrm{v} / \mathrm{v})$ and centrifuged at 7000 r.p.m. for $10 \mathrm{~min}$ at room temperature (Beckman JS 13.1 rotor). The aqueous phase was transferred to another tube and mixed with one-tenth its volume of $10 \%$ CTAB solution $(10 \%, w / v, C T A B, 0.7 \mathrm{M}-\mathrm{NaCl})$ prewarmed to $65^{\circ} \mathrm{C}$. After incubation for $5 \mathrm{~min}$ at $65^{\circ} \mathrm{C}$, the aqueous phase was extracted with an equal volume of chloroform/isoamyl alcohol $(24: 1, \mathrm{v} / \mathrm{v})$ and centrifuged at 7000 r.p.m. for $10 \mathrm{~min}$ at room temperature. The aqueous phase was transferred to another tube, mixed with one-tenth its volume of $10 \% \mathrm{CTAB}$ solution prewarmed to $65^{\circ} \mathrm{C}$, and the extraction repeated. The aqueous phase was transferred to another tube

\section{Table 1. Origin and characteristics of the fungal strains}

Radial growth rate was determined on PDA after $10 \mathrm{~d}$ at $17^{\circ} \mathrm{C}$. Sensitivity to the fungicides benomyl (B), diethofencarb (D) and tebuconazol $(\mathrm{T})$ was determined from the reduction in growth rate in the presence of $1 \mu \mathrm{g} \mathrm{ml}^{-1}$ of the fungicide: $<19 \%$, strain is highly resistant (R); $20-59 \%$, weakly resistant (r); 60-79\%, weakly sensitive (s); 80-100\%, highly sensitive (S). NT, Not tested.

\begin{tabular}{|c|c|c|c|c|c|}
\hline \multirow[b]{2}{*}{$\begin{array}{l}\text { UPM } \\
\text { no.* }\end{array}$} & \multicolumn{3}{|c|}{ Isolation } & \multirow{2}{*}{$\begin{array}{c}\text { Radial } \\
\text { growth rate } \\
\left(\mathrm{mm} \mathrm{d}^{-1}\right)\end{array}$} & \multirow[b]{2}{*}{$\begin{array}{l}\text { Fungicide } \\
\text { sensitivity }\end{array}$} \\
\hline & Date & Host & $\begin{array}{l}\text { Location } \\
\text { (Belgium) }\end{array}$ & & \\
\hline \multicolumn{6}{|c|}{ Pseudocercosporella herpotrichoides: rye-type $†$} \\
\hline 662 & $7 / 89$ & Wheat & Orbais & 0.55 & $B^{R} D^{S} T^{r}$ \\
\hline 663 & $7 / 89$ & Wheat & Orbais & 0.42 & $\mathrm{~B}^{\mathrm{R}} \mathrm{D}^{\mathrm{s}} \mathrm{T}^{\mathrm{s}}$ \\
\hline 664 & $7 / 89$ & Wheat & Villers & $0 \cdot 37$ & $B^{S} D^{R} T^{s}$ \\
\hline 666 & $7 / 89$ & Wheat & Seraing & NT & NT \\
\hline 667 & $6 / 89$ & Wheat & Seraing & 0.40 & $B^{S} D^{R} T^{R}$ \\
\hline 668 & $6 / 89$ & Wheat & Bierwart & 0.52 & $B^{R} D^{R} T^{R}$ \\
\hline 670 & $4 / 89$ & Wheat & Villers & 0.58 & $\mathrm{~B}^{\mathrm{R}} \mathrm{D}^{\mathrm{S}} \mathrm{T}^{\mathrm{R}}$ \\
\hline \multicolumn{6}{|c|}{ Pseudocercosporella herpotrichoides: wheat-type $\dagger$} \\
\hline 672 & $7 / 89$ & Wheat & Villers & 0.55 & $B^{R} D_{i}^{S} T^{S}$ \\
\hline 673 & $7 / 89$ & Wheat & Villers & 0.58 & $B^{S} D^{R} T^{S}$ \\
\hline 674 & $7 / 89$ & Wheat & Villers & $0 \cdot 70$ & $\mathbf{B}^{\mathbf{S}} \mathrm{D}^{\mathrm{R}} \mathrm{T}^{\mathrm{s}}$ \\
\hline 678 & $4 / 89$ & Wheat & Thorembais & $1 \cdot 18$ & $\mathrm{~B}^{\mathrm{S}} \mathrm{D}^{\mathrm{R}} \mathbf{T}^{\mathrm{r}}$ \\
\hline \multicolumn{6}{|c|}{ Microdochium nivale } \\
\hline 645 & $11 / 90$ & Turf grass & Brusen & NT & NT \\
\hline \multicolumn{6}{|c|}{ Rhizoctonia cerealis } \\
\hline 607 & $5 / 90$ & Wheat & Thorembais & NT & NT \\
\hline
\end{tabular}

- UPM, Unit of Phytopathology, Mycological collection, Université Catholique de Louvain, Belgium.

$\dagger P$. herpotrichoides strains are classifed as rye-type or wheat-type depending on the feathery or smooth colony margins, respectively.

containing an equal volume of $\mathrm{CTAB}$ precipitation solution $(1 \%, \mathrm{w} / \mathrm{v}$, CTAB, 50 mM-Tris/HCl, $10 \mathrm{~mm}$-EDTA, pH 8.0) prewarmed to $65^{\circ} \mathrm{C}$. The suspension was then gently mixed to allow precipitation and centrifuged at 7000 r.p.m. for $20 \mathrm{~min}$ at room temperature. The supernatant was then discarded and the pellet resuspended in $3 \mathrm{ml}$ of TE high-salt solution (10 mM Tris/ $\mathrm{HCl}, 0.1 \mathrm{~mm}$-EDTA, pH 8.0), prewarmed to $65^{\circ} \mathrm{C}$, and incubated for $10 \mathrm{~min}$ at $65^{\circ} \mathrm{C}$. The DNA was precipitated by adding a one-tenth volume of $3 \mathrm{M}$-sodium acetate and 2.5 vols cold ethanol, followed by gentle mixing and incubation for $12 \mathrm{~h}$ at $-20^{\circ} \mathrm{C}$. After centrifugation at 7000 r.p.m. for $20 \mathrm{~min}$ at $4{ }^{\circ} \mathrm{C}$, the supernatant was discarded and the pellet washed with $6 \mathrm{ml}$ cold $70 \%$ (v/v) ethanol. Centrifugation was repeated for $10 \mathrm{~min}$ and the supernatant discarded. The pellet was dried for 3-4 min in a speed vacuum and the DNA resuspended in $80 \mu l$ of $1 \times$ TE solution $(10 \mathrm{mM}$ Tris/ $\mathrm{HCl}, 1$ mM-EDTA, $\mathrm{pH} 8.0$ ) and stored at $-20^{\circ} \mathrm{C}$.

Vicia faba DNA was solubilized from isolated nuclei and purified by centrifugation on a $\mathrm{CsCl}$ gradient as described by Boutry \& Chua (1985). Saccharomyces cerevisiae DNA was prepared from lysed protoplasts as described by Ausubel et al. (1989).

DNA required for the construction of the genomic library was purified and fractionated by isopycnic centrifugation in a $\mathrm{CsCl}$ density gradient containing the fluorescent dye bisbenzimide (Hoechst 33258, Sigma) according to Garber \& Yoder (1983), but with an initial $\mathrm{CsCl}$ density of $1.6 \mathrm{~g} \mathrm{ml}^{-1}$. The nucleic acid concentration was estimated by a fluorimetric method involving specific binding of bisbenzimide to DNA.

Construction of a DNA library and probe preparation. Unless otherwise indicated, standard DNA techniques were performed according to 
Sambrook et al. (1989). DNA (20 $\mu \mathrm{g})$ was digested with BamHI (BRL) as recommended by the manufacturer and fragments separated on a $2 \%(w / v)$ agarose gel in TBE [0.13 $\mathrm{M}$-Tris, $0.15 \mathrm{~m}$-boric acid, $3 \mathrm{~mm}$ EDTA, ethidium bromide $\left.\left(5 \mu \mathrm{g} \mathrm{ml}^{-1}\right)\right]$. DNA fragments $0.5-1 \mathrm{~kb}$ long were recovered from gel slices by centrifugation through siliconized sterile glass wool according to Heery et al. (1990), ligated into the BamHI site of pBluescript SK ${ }^{+}$(Stratagene), and used to transform competent cells of Escherichia coli 71-18. Recombinant plasmids were isolated by a $\mathrm{LiCl}$ minipreparation procedure according to Brent (1990) and analysed by agarose gel electrophoresis. Clones were arbitrarily chosen as probes and labelled with $\left[\alpha^{-32} \mathrm{P}\right] \mathrm{dCTP}\left[3000 \mathrm{mCi} \mathrm{mmol}^{-1}\right.$ (111 $\left.\left.\mathrm{GBq} \mathrm{mmol}{ }^{-1}\right) ; 10 \mu \mathrm{Ci}_{\mu l^{-1}}\left(370 \mathrm{kBq} \mathrm{ml}^{-1}\right)\right]$ by the nick-translation method as recommended by the manufacturer (BRL).

Southern blot and dot-blot hybridization. For Southern blot experiments, DNA was digested with EcoRI or HindIII, separated by electrophoresis through a $1.5 \%(w / v)$ agarose gel in TBE, and transferred to nylon membranes (Hybond $\mathrm{N}^{+}$, Amersham) according to the manufacturer's instructions. For dot-blot experiments, DNA was directly spotted onto nylon membranes as recommended by the manufacturer. Hybridizations were performed at $42{ }^{\circ} \mathrm{C}$ (Sambrook $e t$ al., 1989), the probe activity being $4 \times 10^{6}$ c.p.m. $\mathrm{ml}^{-1}$. Blots were washed in $0.5 \times$ SSC and $1 \%(\mathrm{w} / \mathrm{v})$ SDS for $3 \mathrm{~h}$ at $65^{\circ} \mathrm{C}$ and exposed to $\mathrm{X}$-ray films (X-OMAT AR, Kodak) at $-80^{\circ} \mathrm{C}$ with an intensifying screen. Re-use of blots was possible after removal of the probe by immersion of the membrane in boiling $0.5 \%$ SDS and cooling to room temperature.

\section{Results}

To obtain DNA probes capable of revealing polymorphisms among $P$. herpotrichoides isolates, we constructed a partial genomic library of the W-type isolate UPM672. Purified nuclear DNA was cut with the restriction enzyme BamHI. DNA fragments $0.5-1 \mathrm{~kb}$ in length were isolated from preparative gel electrophoresis and cloned in a bacterial plasmid.

Twenty recombinant clones were randomly chosen, ${ }^{32}$ P-labelled, and hybridized with HindIII- or EcoRIcleaved genomic DNA from R-type (UPM662) and Wtype (UPM672) isolates. One of the probes (Psh19.42, Fig. 1 probe 1) gave a strong signal, and thus might contain a DNA repeat sequence. All the other probes but one gave one or two hybridizing bands, differing in size between the R-type and W-type of $P$. herpotrichoides, regardless of the restriction enzyme used. Fig. 1 illustrates the hybridization patterns obtained with five of the probes tested. Two probes (Psh20.37 and Psh19.42) gave a signal with the W-type only. We conclude that these sequences are specific to the W-type or that the corresponding sequences in the R-type are highly heterologous.

The general ability of our probes to reveal polymorphisms between closely related individuals was tested with a combination of five clones producing signals of different sizes in Southern hybridization experiments performed with EcoRI-digested total DNA (Fig. 2a). Such a combination allowed easy determination of the

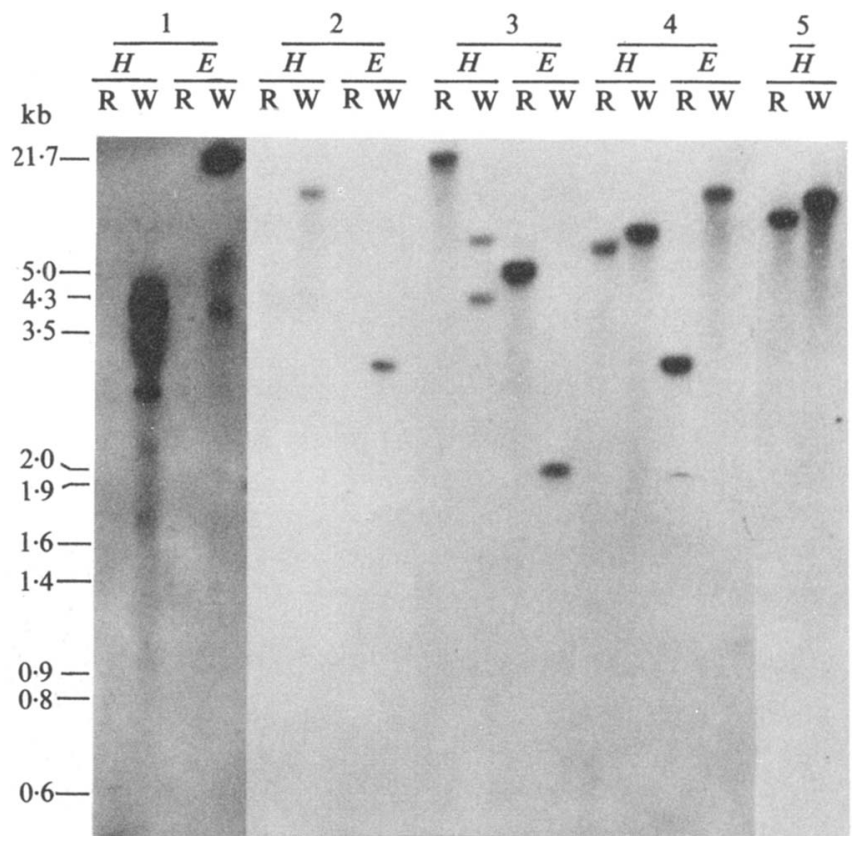

Fig. 1. Southern blot hybridization of R-and W-type genomic DNA with probes derived from a W-type isolate of $P$. herpotrichoides UPM672. Genomic DNA $(1 \mu \mathrm{g})$ extracted from the UPM662 R-type $(R)$ and UPM672 W-type (W) isolates was digested with the restriction enzymes HindIII $(H)$ or $E c o$ RI $(E)$, electrophoresed and transferred to nylon membranes. Hybridizations were performed with ${ }^{32} \mathrm{P}$-labelled DNA of the following clones: Psh19.42 (1), Psh20.37 (2), Psh20.39 (3), Psh20.40 (4) or Psh20.38 (5).

two types of $P$. herpotrichoides within a group of 11 field isolates, while no signal was obtained with DNA from two other pathogenic fungi of the cereal stem base, Rhizoctonia cerealis and Microdochium nivale. Furthermore, several isolates within each morphological type could be singled out by their specific restriction fragment pattern (Fig. 2a). Three classes were observed for the seven R-type isolates while each of the four isolates of Wtype gave a different pattern. Similar differences were detected among four monocaryotic ascospores of each type (results not shown). As shown in Fig. 2(b), signals were obtained with W-type isolates only, when a similar blot was hybridized with the W-type-specific probe Psh19.42 (Fig. 1, lane 1). With this probe, it was possible to distinguish between the four isolates, as the hybridization patterns varied considerably.

The high signal intensity and the W-type specificity observed with the Psh19.42 probe, whose restriction map is shown in Fig. 3, led us to test this DNA fragment in dot-blot hybridizations with DNA extracts derived from the two morphological types of $P$. herpotrichoides and to evaluate its possible use in diagnosis. Thus, serial dilutions of DNA were hybridized from the R- and Wtypes analysed in Fig. 2, alongside $M$. nivale and $R$. cerealis and three additional controls: a Penicillium sp., 


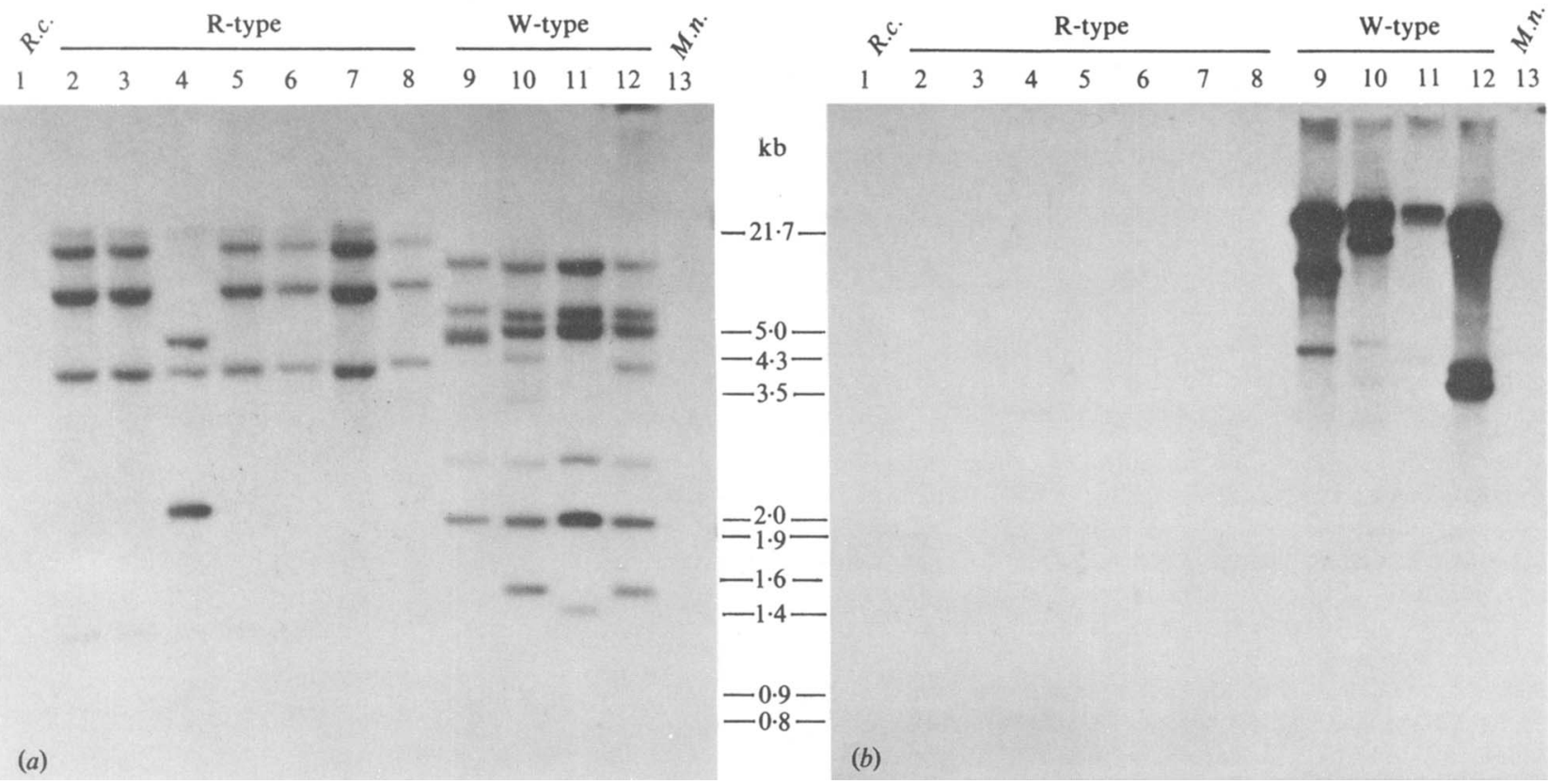

Fig. 2. Southern blot analysis of several R-and W-type isolates of $P$. herpotrichoides. Total DNA from the seven R-type and the four Wtype isolates of $P$. herpotrichoides listed in Table 1 and from one isolate each of $R$. cerealis $(R . c$.) and $M$. nivale $(M . n$.) was hybridized with a combination of the Psh19.13, Psh19.48, Psh19.17, Psh19.22 and Psh19.29 clones $(a)$ or with the Psh19.42 clone alone (b). From left to right, DNAs were from isolate UPM607 of $R$. cerealis (1); from isolates UPM670 (2), UPM668 (3), UPM667 (4), UPM664 (5), UPM666 (6), UPM663 (7) and UPM662 (8) of the R-type of P. herpotrichoides; from isolates UPM672 (9), UPM673 (10), UPM674 (11) and UPM678 (12) of the W-type of $P$. herpotrichoides; and from isolate UPM645 of $M$. nivale (13).

Bam HI

BamHI

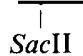

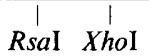

RsaI

Fig. 3. Restriction map of the P. herpotrichoides BamHI DNA insert of the Psh19.42 clone. Total length of the insert is $0.95 \mathrm{~kb}$.

Saccharomyces cerevisiae and Vicia faba (broad bean). Signals were obtained with DNA from the W-type only (Fig. 4a). For all four W-types, $0.5 \mu \mathrm{g}$ of DNA was sufficient to produce a signal after a $1 \mathrm{~d}$ exposure. As a control, we hybridized the same blot with another probe (Psh20.38, lane 5 of Fig. 1) which gave a signal with all isolates of $P$. herpotrichoides analysed (Fig. $4 b$ ).

\section{Discussion}

We have hybridized several DNA probes derived from a W-type $P$. herpotrichoides strain with DNA prepared from strains, either of the same type or the R-type. Most of the probes gave one- or two-band signals of similar intensity, showing that they probably came from a single-copy sequence. In no case was the size of hybridizing fragments the same for both $P$. herpotrichoides types, which reflects a high degree of polymor-
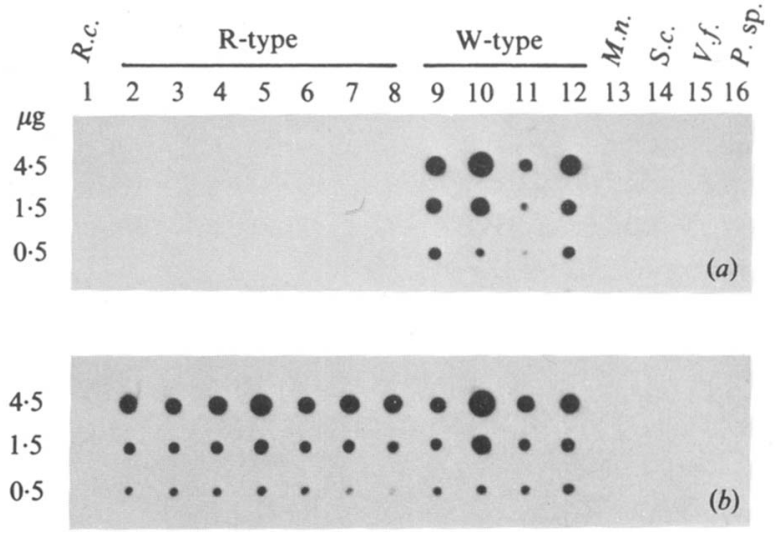

Fig. 4. Dot-blot hybridization of total DNA of the R-and W-types of $P$. herpotrichoides with a $R$-type specific probe. Total DNA from the following was spotted on a nylon membrane: isolate UPM607 of $R$. cerealis (1, R.c.); isolates UPM670 (2), UPM668 (3), UPM667 (4), UPM664 (5), UPM666 (6), UPM663 (7) and UPM662 (8) of the R-type of $P$. herpotrichoides; isolates UPM672 (9), UPM673 (10), UPM674 (11) and UPM678 (12) isolates of the W-type of $P$. herpotrichoides; isolate UPM645 of $M$. nivale (13, M.n.); Saccharomyces cerevisiae (14, S.c.); Vicia faba $(15, V$.f.); and a representative of the genus Penicillium (16, P.sp.). The same blot was hybridized with the Psh 19.42 clone (a) and with the Psh20.38 clone (b). The amount ( $\mu \mathrm{g})$ of DNA spotted is indicated on the left.

phism between their respective genomes. This molecular-level observation is in keeping with the reported vegetative incompatibility of these two types (Hocart $e t$ al., 1989). It raises the possibility of distinguishing 
between the two types. Furthermore, two probes were found to hybridize with the W-type only. One, (Psh19.42), which probably contains a multicopy sequence, was able to distinguish W-types from R-types in a dot-blot hybridization experiment. In Southern blot experiments, a mixture of five probes could distinguish the four representatives of the W-type and three different patterns among the seven representatives of the R-type. Further testing is required to ensure that these probes can distinguish between a wide variety of W-and R-type isolates. In addition, such tests should be carried out in concert with rigorous pathogenicity testing to ensure complete compatibility between the two characterization methods. It is interesting to note that the 11 strains used in this study could not clearly be classified according to phenotypic traits such as growth rate and fungicide sensitivity (Table 1).

Recently, DNA polymorphism in $P$. herpotrichoides has been investigated with a ribosomal RNA probe derived from the wheat genome (Nicholson et al., 1991). In agreement with the results presented here, a higher degree of polymorphism was also observed in the Wtype. In comparison to other classification methods, the advantages of RFLP technology are numerous. Paramount is the fact that DNA hybridization signals are fully reproducible and do not vary with culture age or growth conditions. The high sensitivity of the method is another great advantage. With powerful techniques such as the polymerase chain reaction (PCR), it is conceivable that molecular approaches at DNA level will enable us to detect the presence of specific types in the field without requiring any in vitro culture.

We thank J. M. Moreau for his advice and for providing us with the strains, A. M. Faber for her help, Dr M.-C. Flamand and S. Vanderstraeten for providing us with the $V$. faba and $S$. cerevisiae DNA and $\operatorname{Dr} \mathrm{A}$. Goffeau for financial support.

\section{References}

Ausubel, F. M., Brent, R., Kingston, R. E., Moore, D. D., Seidman, J. G., Smith, J. A. \& StruHL, K. (1989). Current Protocols in Molecular Biology, pp. 13.11.1-13.11.2. New York: John Wiley.

BouTRY, M. \& CHUA, N.-H. (1985). A nuclear gene encoding the beta subunit of the mitochondrial ATP synthase in Nicotiana plumbaginifolia. EMBO Journal 4, 2159-2165.

BRENT, R. (1990). The red book bulletin. Supplement 11. In Current Protocols in Molecular Biology. Edited by F. A. Ausubel, R. Brent, R. E. Kingston, D. D. Moore, J. G. Seidman, J. A. Smith \& K. Struhl. New York: Green Publishing and Wiley-Interscience.

Creighton, N. F. (1989). Identification of W-type and R-type isolates of Pseudocercosporella herpotrichoides. Plant Pathology 38, 484-493.

Creighton, N. F. \& Bateman, G. L. (1991). Problems in identifying pathogenicity types of Pseudocercosporella herpotrichoides by colony morphology arising from the source and concentration of the nutrient agar. Mycological Research 95, 253-254.

FitT, B. D. L., Goulds, A. \& Polley, R. W. (1988). Eyespot (Pseudocercosporella herpotrichoides) epidemiology in relation to prediction of disease severity and yield loss in winter wheat - a review. Plant Pathology 37, 311-328.

GARBER, R. C. \& YODER, O. C. (1983). Isolation of DNA from filamentous fungi and separation into nuclear, mitochondrial, ribosomal and plasmid components. Analytical Biochemistry 135, 416-422.

Goulds, A. \& Polley, R. W. (1990). Assessment of eyespot and other stem base diseases of winter wheat and winter barley. Mycological Research 94, 819-822.

Heery, D. M., Gannon, F. \& Powell, R. (1990). A simple method for subcloning DNA fragments from gel slices. Trends in Genetics 6, 173.

Hocart, M. J., Lucas, J. A. \& Peberdy, J. F. (1989). Vegetative incompatibility in Pseudocercosporella herpotrichoides. Plant Pathology 38, 478-483.

Hollins, T. W. \& ScotT, P. R. (1987). Eyespot. Take-all. Sharp eyespot. In Annual Report of the Plant Breeding Institute for 1986, pp. 100-102. Cambridge: Plant Breeding Institute.

Holins, T. W., ScotT, P. R. \& Paine, J. R. (1985). Morphology, benomyl resistance and pathogenicity to wheat and rye of isolates of Pseudocercosporella herpotrichoides. Plant Pathology 34, 369-379.

KING. J. E. \& GRIFFIN, M. J. (1985). Survey of benomyl resistance in Pseudocercosporella herpotrichoides on winter wheat and barley in England and Wales in 1983. Plant Pathology 34, 272-283.

lagneau, C., Dandois, J., Bastin, V., Poncelet, J. \& Maraite, H. (1986). Evolution et sévérité des maladies sur froment d'hiver et escourgeon en 1985. Mededelingen Faculteit Landbouwwetenschappen Rijksuniversiteit Gent 51, 603-616.

LaNGe-De La CaMP, M. (1966). Die Wirkungsweise von Cercosporella herpotrichoides Fron dem Erreger der Halmbruchkrankheit des Getreides. Phytopathologische Zeitschrift 55, 34-66.

Leroux, P. \& GREDT, M. (1988). Caractérisation des souches de Pseudocercosporella herpotrichoides, agent du piétin-verse des céréales, résistantes à des substances antimitotiques et à des inhibiteurs de la biosynthèse des stérols. Agronomie 8, 719-729.

LIND, V. (1990). Isolation of antigens for serological identification of Pseudocercosporella herpotrichoides (Fron) Deighton. 1990. Zeitschrift für Pflanzenkrankheiten und Pflanzenschutz 97, 490-501.

Maraite, H., Delforge, C., Meunier, S. \& Tetelain, A. (1985). Distribution of MBC-resistance in Pseudocercosporella herpotrichoides in winter wheat in Belgium. Mededelingen Faculteit Landbouwwetenschappen Rijksuniversiteit Gent 50, 1173-1180.

Mauler, A. \& FehrmanN, H. (1987). Erfassung der Anfälligkeit von Weizen gegenüber Pseudocercosporella herpotrichoides. I. Untersuchungen zur Pathogenität verschiedener Formen des Erregers. Zeitschrift für Pflanzenkrankheiten und Pflanzenschutz 94, 637-648.

Nicholson, P., Hollins, T. W., RezanooR, H. N. \& Anamthawat Jonsson, K. (1991). A comparison of cultural, morphological and DNA markers for the classification of Pseudocercosporella herpotrichoides. Plant Pathology 40, 584-594.

NiRENBERG, H. I. (1981). Differenzierung der Erreger der Halmbruchkrankheit. I. Morphologie. Zeitschrift für Pflanzenkrankheiten und Pflanzenschutz 88, 241-248.

RoGERs, S. O. \& BENDICH, A. J. (1988). Extraction of DNA from plant tissues. In Plant Molecular Biology Manual, part A6, pp. 1-10. Edited by S. B. Gelvin, R. A. Schilperoort \& D. P. S. Verma. Dordrecht: Kluwer Academic Publishers.

Sambrook, J., Fritsch, E. F. \& Maniatis, T. (1989). Molecular Cloning, A Laboratory Manual. Cold Spring Harbor, NY: Cold Spring Harbor Laboratory.

Sanders, P. L., De WaARd, M. A. \& Loerakker, W. M. (1986). Resistance to carbendazim in Pseudocercosporella herpotrichoides from Dutch wheat fields. Netherlands Journal of Plant Pathology 92, $15-20$.

SCOTt, P. R., Hollins, T. W. \& MuIR, P. (1975). Pathogenicity of Cercosporella herpotrichoides to wheat, barley, oats and rye. Transactions of the British Mycological Society 65, 529-538.

Wegge, D. Poupard, P., Frei, U. L. \& Lind, V. (1991). Electrophoretic identification of pathogen-specific proteins of foot-rot inducing fungi of wheat. Zeitschrift für Pflanzenkrankheiten und Pflanzenschutz 98, 1-12. 